\title{
The SEMINARY of GREGORY XIII in VILNIUS $(1583-1655)^{*}$
}

\author{
Artūras GRICKEVIČIUS \\ Vilnius Pedagogical University
}

The end of the sixteenth century and the beginning of the seventeenth was one of the most significant and distinctive periods in the history of Lithuania. The confrontation between the Catholics and Protestants in the Grand Duchy of Lithuania resulted in the flourishing of European culture there, its peak undoubtedly being the Academy of Vilnius. The Vilnius Pontifical Seminary ${ }^{1}$ was a component part of the Academy. Due to the scarcity of sources relating to the studies at the Academy, a more comprehensive investigation of the activity of the Seminary could shed additional light on the Academy itself. The functioning of the Semenary was also of major importance for neighbouring nations - the Russians, the Latvians, the Estonians, the Swedes, the Germans (in relation to Prussia), etc., because quite a number of them were its alumni, who afterwards went back to their native countries to work for the benefit of the Church and their people. The history of the Seminary reflects the endeavours of the local Church province in the spiritual integration of Livonia - a dependency of the Polish-Lithuanian Republic (later - of a part of it). This subject is also important in respect to the efforts of the Vatican to integrate the Orthodox Ruthenians and Muscovians into Roman Catholicism. After the Union of Brest (1596) the activity of the Vilnius Seminary was also associated with the further develogment of the Uniate Church. However, the contribution of the Seminary to union has not yet been properly investigated. ${ }^{2}$ The Vilnius Semenary was one of many such pontifical seminaries, and the elucidation of its history, the activity of the Jesuits and the Sacred Congregation of the Evangelization of Peoples $^{3}$ in respect to the Seminary broadens the knowledge of the general process of the European Catholic reform.

*This paper, containing some minor corrections, is mainly based on the author's doctoral thesis Popiežiškoji seminarija Vilniuje 1583-1655 (The Pontifical Seminary of Vilnius in 1583-1655), presented at the University of Vytautas Magnus on 1 July 1997.

'Pontificium seminarium Vilnense, hercafter the PSV.

${ }^{2}$ D. Blażcjovskij. Byzantine Kyivan rite students in the pontifical colleges, and in seminaries, universities and institutes of central and western Europe. Romc, 1984, 51: The Collcge of Vilno is a black spot in the history of the Union $\langle\ldots\rangle$.

${ }^{3}$ Sacra Congregazionc per l'Evangelizzazione dei Popoli, hercafter the Sacred Congregation. 
The problematic nature of this research is conditioned by controversial, poorly (if at all) documented statements (including those found in the encyclopaedias) about the character and purpose of the Seminary. It is called both a hostel and an alumnatus and is attributed to either the Ruthenians or the Uniates, etc. ${ }^{4}$ The functioning of the Seminary has been dealt with only superficially and has not yet been subjected to a complex systematic analysis. ${ }^{5}$ Difficulties also arise due to the absence of a more comprehensive work on pontifical seminaries in general. ${ }^{6}$

In this research is based on published ${ }^{7}$ and unpublished sources. The overwhelming majority of the latter are preserve in Rome. ${ }^{8}$

${ }^{4} \mathrm{Cf}$. Й. Сліпий. Історичний огляд вихования духовенства в католицькій Церкви загалом і зокрема на Украіни. Opera Greca Catholicae Academiae Theologicae Leopoli. 1935, V. 1-2, 28; R. Holowackyj. Seminarium Vilnense SS. Trinitatis (16011621). Romac, 1957, 33; D. Blażcjowskij. Byzantine 30; Vilniaus akademijos vizitatoriu memorialai ir vyresniuju nutarimai. Vilnius, 1987, 282; Tarybu Lietuvos enciklopedija. Vilnius, 1988, t. 4, 545; Vilniaus universiteto istorija. 1579-1994. Vilnius, 1994, 44.

Cf. J. Poplatck. Zarys dzicjów Scminarjum Papicskicgo w Wilnic 1585-1773. Ateneum Wilenskie. 1930, r. VII, z. 1-2, 17()-228; O. Garstcin. Rome and the counter-reformation in Scandinavia. Leiden, ctc., 1992, V. 1, 234-265, 352-365; H. Litwin. Przynalcżność narodowa alumnów Seminarium Papieskiego w Wilnie 1582-1798. Między wschodem a zachodem. Warszawa, 1993, 61-65; in greater detail sec: A. Grickevičius. Popiežiškoji .., 8-15.

${ }^{6} \mathrm{Cf}$. Sacrae Congregationis de Propaganda Fide memoria rerum, vol. I, pars I, Rom u. a, 1971, 483-505; D. Blażcjovskij., Byzantine ..., ; P. Schmidt. Das Collegium Germanicum in Rom und die Germaniker. Tübingen, 1984; J. Leinwebcr. Das Päpstliche Seminar in Fulda und seine Bedcutung im Zcitalter der Katholischen Erneucrung und des Barock. Ecclesia Peregrinans, Wien, 1986, 185-194; Z. Hojda. Collegia nordica v Olomouci a Branieve 15781619. Acta Universitatis Carolinae. Historia Universitatis Carolinae Pragensis. 1990, t. 30, facs. 1, 49-95; O. Garstcin. Rome... E.g., in recent publications, referring to the seminaries, no mention is made of special studies; sec: K. Jaitner. Dic Päpstliche Kirchenreformpolitik von Gregor XIII. bis Gregor XV. Katholische Reform und Gegenreformation in Innerösterreich 1564-1628. Klagenfurt u.a., 1994, 282. Regrettably the same is the situation with the research of the episcopal scminaries - that was noted by Hubcrt Jedin already in 1958 (H. Jcdin. Domschulc und Kollcg. Trierer Theologische Zeitschrift. 1958, Bd. 67, 222223). This kind of work, at least related to entire Europe until the secularization, has not yet becn produced. More about the historiography of pontifical seminaries see: A. Grickevičius. Popiežiš̌koji ..., 15-16.

${ }^{7}$ Among them these are the most important:

Acta Sacrae Congregationis de Propaganda Fide res gestas Bohemicas illustrantia, vol. 2, Prag, 1954; Vello Hclk. Dansk-norske studierejser fra reformationen til enevcelden 15361660. Odcnsc, 1987; Gcorg Lühr. Die Matrikel des päpstlichen Seminars zu Braunsherg 1579 1798. Braunsherg, 1925; Monumenta Ucrainae Historica. Romac, 1964, 1965, 1974. Vol. 1 - 3, 9-11; J. Poplatck. Wykaz alumnów Scminarjum Papicskicgo w Wilnic 1582-1773. Ateneum Wileńskie. 1936, r. XI, 218-282; Vilniaus akademijos vizitatoriu memorialai ir vyresniuju nutarimai. Vilnius, 1987; Россия и Италия. Сборник исторических материалов и исследований, касающихся сношений России с Италией. С. Петербург, 1911. T. 1. B. 2. For commentarics on these and other published works sec A. Grickevčius. Popiežiškoji ..., 16, 18, 20, 23, 177-179.

${ }^{8}$ Among the unpublished sources the most significant are the following:

Archivum Romanum Socictatis Icsu:

Alumni S.D.N. Pont. Max. qui Vilnac degunt hoc anno 1592. Lith.36. N. 117; Catalo- 
However, all these sources could hardly have shed sufficient light on many issues, since some aspects and periods were not adequately presented. To overcome these difficulties the missing facts had to be reconstructed taking into account the system and the process of the contemporary studies and having at one's disposal several scores of thousands of facts. Processing these data with the help of a computer produced original conclusions. Regrettably, they are not applicable to the entire period of 1583-1655, but only to the years between 1585 and 1602 and between 1623 and 1655 .

\section{The Reform of the Catholic Church and the Seminaries}

After Pope Julius III founded the German college at Rome in 1552 and, at the Synod of the Catholic Church of England in 1555-56 Cardinal Pole ordained that all bishops of the country had to set up seminaries, in 1563 the Council of Trent issued the so-called seminary decree, according to which the bishops were obliged to establish seminaries/colleges, where young men of poor families could study Latin and be trained for priesthood. Additionally the Council decided to reorganize the training of the clergymen so that they could acquire deeper theological knowledge. Thus the decree on the establishment of the seminaries specified only the recruitment of students, their initial studies and spiritual education. All the other issues were put at the disposal of the bishop. In that way the Church Synod resolved to gat-

gus alumnorum Pontificis Maximi Scminarii Vilncnsis anni 1590. Lith. 36. N. 115. F. 289v290; Catalogus alumnorum pontif. Vilnac ab initio seminarii a. 1602 missus in Urbem a Patrc Paulo Boxa in martio. F. Ges. 1652/3/12; Catalogus corum alumnorum, qui hoc proximo quadricnnio partim ad laborandum in vinca Domini, partim ad Religionem missi sunt. Lith. 36. N. 119; Catalogus ct examinatio facta Vilnac alumnorum ct aliorum qui sunt in Scminario Pontificis. Opp. NN. 325. F. 36v-37; Catalogus omnium alumnorum Vilnae anni pracsentis 16()2. F. Gcs. 1652/3/13; In Scminario Vilnensi disposita a. R. P. Posscvino mense iulio anni Domini 1585. Opp. NN. 325 F. 26v-27r; Nomina corum qui relicti sunt in Scminario Pontificio Vilnensi anno 158510 iulii. Opp. NN. 325. F. 33r; Nomina corum qui sunt in Seminario Pontificio Vilncnsi. Lith. 36. N. 118; Scminaristac hoc anno fucrunt in universum 10 absq. Hermano Rigensi. Opp. NN. 326. F. 318v. 322v; Status Seminarii Wilnonsis Pontif. Maxi. anno 1592. Lith. 36. F. 291r-292r.

Archivio Storico della Sacra Congregazione per l'Evangelizzazione dei Popoli:

Acta Sacrac Congregationis de Propaganda Fide. V. 3, 7, 8, 10, 12, 13, 15, 17-20), 25; Lettcre volgari della Sacra Congregazionc. V. 4, 5, 8, 11-19: Scritturc originali riferitc nelle Congregazioni Gencrali. V. 56, 58, 365; Visitc c collegi. V. 1, 3-8, 10-13, 15, 16, 18, 19, 21, 23 (Pars 2), 26, 28, 29.

Biblioteca Apostolica Vaticana:

Codex Vaticanus latinus. 8473.1.

Manuscript Department of the Vilnius University Library:

Bulla crectionis Seminarii Vilnac pro Ruthenis. F. 57. B. I 553-37; Laureac academicac scu liber continens ritum promovendi ct catalogum promotorum ad gradum doctoratus, licentiatus, magisterii et baccalaurcatus in alma Academia Vilnensi Societatis Jesu comparatus ct ordinatus anno 1650. F. 2. B.Dc-1.

More about these and other unpublished sources of the history of the Vilnius Semenary scc: A. Grickcvičius. Popiežiškoji ..., 18-20, 21-22, 23, 179-181. 
her the workers for the Lord's vineyard from the poor, i.e., from those who were few in that field at that time.

Though the decree of the Council obliged only the bishops and not the Pope, colleges were set up in Rome for the Greeks, the neophytes, the English, the Armenians and the Maronites, and later, not any more in Italy, for young men of other nations. From the theological viewpoint, the Pope founded the seminaries as the bishop (pastor) of the entire Church of Jesus. Thus in essence they did not differ from those established by ordinary bishops, since the purpose of both types of institutions basically was the same, namely, to train young men for the Church. Thus, the need to gather and train the youth for the Church and to prepare better priests was satisfied in two ways: in the pontifical seminaries, set up in Rome and later also elsewhere, and in the seminaries, founded by the ecclesiastical superiors in various countries. That was the origin of the pontifical and episcopal seminaries.

Apart from the founder (Pope / bishop), the two types of seminaries differed in respect to their curators (the Jesuit general / the Sacred Congregation or the Chapter), to the sources of financing (pontifical / local), and especially to their purpose. The pontifical seminaries, even those set up for certain non-Catholic or confessionally mixed countries, had to serve the needs of the entire Church rather than those of that particular country. Though there are no comprehensive investigations, some statements, found in historiography, as well as the author's observations, revealed by the analysis of the collected material, display one more specific feature of the pontifical seminaries, namely, not all their alumni became clergymen." Some of them acted as auxiliaries in the missions, during/after the studies at the Translators' Seminary of Dorpat they worked on the translations of Catholic literature into their native vernaculars, and, wherever that was possible, just imparted the truths of the Catholic Church by personal example and word in their homeland. In that way the character of the pontifical seminaries in those times differed from that of the episcopal seminaries, training only priests. The pontifical seminaries can also be considered as centres for the education of Catholic youth and in particular of the converts, and also for the preparation of secular priests and missionaries. Through its seminaries the Holy See could directly influence the training of priests in particular countries.

Both pontifical and episcopal seminaries were loosely regulated, and as flexible institutions they could easily be adapted to the situation of each individual country. The principal aim of their establishment was the renewal of the Catholic Church; while the pontifical

"In addition to regular students (alumni pontificii), supported from the papal means, pontifical scminarics also had convictors/commoners (convictores), who paid for their upkecp. In this paper only the former are referred to as students. 
seminaries, additionally, were entrusted with the task of spreading the Catholic faith. The latter seminaries were a means of challenging the epoch, they were a product of creation rather than administration, and one of the main (if not the most important) reasons for the appearance of both types of seminaries was the necessity to carry out the Catholic reform. Its realization had to return back to the Catholic Church the children and grandchildren of the apostates and to educate a new clergy, which, in its turn, would contribute to the rise of spiritually more mature high-minded believers.

\section{The Seminary as an Individual Institution and its Purpose}

The Pontifical Seminary of Vilnius was founded by the papal bull of Gregory XIII on 5 February $1583 .{ }^{10}$ Its normal functioning, however, started only on 10 July 1585 after a formal inauguration. The Semenary did not have any specific integral legal code or statute, defining its status and activity. The legal basis of its establishment was the papal bull, and its functioning was determined by several sets of regulations and rules (the regulations of the seminary and the rules for the students), a certain part of which was often referred to by the historians as a statute. The oath of the students was of major importance. In the period under investigation there were some variants of the oath, and its changes practically modified the character of the Seminary. The students were taught according to the Jesuit Ratio studionum.

Looking upon the Seminary as an separate institution, it must be stated that it was not only a place of material support but of education as well. A specially appointed College Jesuit or, very often, one or even two masters from the personnel of the had to assist the rector not only to administer the seminary and supervise the students, but also to regulate their studies and teach them. A special time and place were indicated for the studies, and new books were regularly acquired for the library. Teaching of languages was conducted at many seminaries, including the. It can be maintained that at the students were taught at least those subjects, which were then in the syllabus of the academy; lessons were also given in how to deliver sermons (in Latin and other languages) and in other subjects (including music), necessary for the future clergymen. For example, there are indications that a separate programme of controversial theology was designed for the Braunsberg pontifical seminary Braunsberg Seminary. Even professors could have been appointed for the teaching of such subjects at both (pontifical and episcopal) seminaries of Vilnius. Though the pontifical seminary functioned at the Jesuit Academy, nevertheless legally it was a separa-

${ }^{10}$ Scc: A. Grickevičius. Popiežiškoji ..., 32, 34. 
te institution, which could be defined as an establishment of rigidly oriented education and non-autonomous teaching.

Although, as is evident from the bull, the was intended for the education of the Ruthenians and the Muscovians in order to convert them to the Catholic faith, it soon became evident that among them hardly anyone wanted to become either a student or a Catholic. The Jesuit priest Antonio Possevino, the initiator of the new seminary and its principal organizer, permitted the enrolment of other students, but Orthodox and Protestant children retained their preference. ${ }^{11}$ Therefore even before the official opening, i.e., between December 1583 and June 1585 students of other nationalities rather than Ruthenians and Muscovians predominated. In 1590 the regulations of the Pontifical Seminaries of Olomouc and Braunsberg were adopted in the Vilnius Semenary, enabling the enrolment of students "from Sweden, Gothia, Vandalia, Norway, Denmark, Pomerania, Prussia, Livonia, Muscovy, Rus' or Lithuania, Hungary", ${ }^{2}$ and making the PSV an ordinary pontifical seminary, the purpose of which was to educate the converts of both local and neighbouring lands. In the period under investigation the Vilnius Semenary was neither Collegium Russicum, nor Seminarium Rutenorum, it was a typical pontifical seminary, in no way differing from similar institutions of Central Europe. Between 1585 and 1624 legally it was not a seminary for training the priesthood. In 1625 the wording of the oath of the students was modified, in 1632 it was adopted in Vilnius as well, and that changed the type of the seminary. It started training only secular priests.

\section{Roman patronage for the Seminary}

From the time of its establishment by the papal bull, the PSV was under the aegis of the rector of the Academia Vilnensis. However he did not take any active part its administration, since management was conducted in this hierarchical order: Head of the Seminary - Pro-

${ }^{11} \mathrm{~J}$. Poplatck. Powstanie ..., z. 3-4, 435, 436.

${ }^{12}$ Sec: A. Grickevčius. Popiežiškoji ..., 56. Some of these ethnic names (namely, Gothia and Vandalia, Rusia and Lithuania) should be dealt with in greater detail. The first of them does not denote the island of Gotland, but an area in continental Sweden - Götaland. The sccond name is problematic - it might be identified with the land of the Sorbians; sec the author's thesis, p. 70. In the corresponding regulations of the Pentifical Seminary of Braunsberg and Olomouc the names of Russia and Lithuania are invariably presented together, i.c., they cither complement or replace each other: Russia seu Lithuania. In that way possibly the stress was laid on the fact that the Seminary admitted only young men from the land, called Russia or Lithuania, to be more precise, from the 'Lithuanian' Russia, or from the Russia, bclonging to the Grand Duchy of Lithuania, but not from the Polish lands of the same name or from the genuinc Lithuania. The original wording of Cardinal Ptolomeo Galli's directive has not been preserved and his exact formulation relating to the Vilnius Pontifical Semenary is not known. Nevertheless, the analysis of the origin of the Scminary's students convincingly demonstrates that 'Russia and Lithuania' were meant. 
vincial - General. The routine questions were settled the local Jesuits. Both the superiors of the Order and the local Jesuits treated the Seminary as an appendage of the Academy. The activity of the Seminary did not cause any problems or doubts for the Holy See, therefore it can be surmised that the management of the school did not contradict the papal orientation.

The Sacred Congregation treated the issue differently, considering the Seminary a legally independent missionary college. Between 1624 and 1628 the Sacred Congregation became acquainted with the situation there, and after several years (in 1633) constant cooperation started between it and the governing body of the Seminary. The Sacred Congregation, however, could not go into the particulars, because it was too busy with lots of other problems and scores of seminaries, and the speed of communication was slow. Patronage from Rome was also not easy due to the intricacy of clerical work, the absence of uniform (geographical) terminology and the frequent changes of the leadership - administrators (rectors), curators (Jesuit generals, later the officials of the Sacred Congregation, invested with official duties of seminary patronage), intermediaries (Jesuit provincials, and papal nuncios) and even due to the changes of clerks in the chanceries of those superiors. Therefore the control of the seminary often was ineffective, and the decisions of the SC were based on a superficial knowledge of the situation. The Sacred Congregation attempted to entrust the nuncio with at least a part of the control functions, however, residing in Warsaw he could not do much. Later, about the year 1639, the Jesuit provincial took over that responsibility, and thus, at the end of the period under investigation, the control was exercised jointly by the Jesuits and the Sacred Congregation. Despite all the organizational difficulties the management of the Seminary from Rome improved and its functioning became more efficient. After 1625 the Holy See actually was satisfied with the assignment of the Seminary and only slightly corrected its activity.

By taking over the control of the pontifical seminaries, the Sacred Congregation caused some discontent of the Jesuits who only after some time unwillingly recognized the right of the Congregation to the management of the Seminary. Normal cooperation between these two institutions was re-established only about the year 1633. Nevertheless, the Sacred Congregation did not quite trust its partners, and that friction weakened the possibility of the Seminary to act in the direction, indicated by the Sacred Congregation. A rigid stance of the Sacred Congregation prevented the Jesuits from recruiting novices from their bright and active alumni. The Sacred Congregation, in general, valued the activity of the Seminary, run by the Jesuits, considering them indispensable in that field. 


\section{The Students}

The majority of the students were admitted through the recommendation of the Jesuits. Later the Basilians started sending their pupils, and they were also enrolled at the request of the bishops of Vilnius, Samogitia and Warmia. There were no admittance quotas for any particular areas, though some bishops - the Uniate metropolitan Joseph Velamin Rutskyj and the bishops of Samogitia and Smolensk (the latter two - unsuccessfully) tried to obtain a fixed number of places for their students. The fact that the requests of these bishops, having at their disposal large areas, inhabited by great numbers of people of other Christian confessions, were rejected reveals the contradiction between the local needs of the Catholic Church and the financial policy of the Holy See, not intending to establish any new seminaries therefore it was impossible to allocate places (quotas) for particular bishoprics in the existing schools without harming the interests of other areas.

Between 1585 and 1602 there were 197 or 199 students at the Seminary; between 1623 and 1655 that number was no less than 174 , and during the whole period of 1583-1655 the number of students was over 500 .

In the period of 1585-1602 among the total number of 199 students the following countries and lands were represented by one student (0.5 per cent): Austria, Belgium, Bohemia, Dalmatia, Hamburg, Hessen, Illyria, Italia, Lapland, Lübeck, Muscovy, Mazuria and Norway; by two students (1.0 per cent) - Finland, Silesia, Samogitia and Swabia; by three students (1.5 per cent) - Podlasia and Transylvania; by four students ( 2.0 per cent) - Germany, ${ }^{13}$ Saxony and Westphalia; by five students ( 2.5 per cent) - Brandenburg, England, Hungary and Scotia; there were six students (3.0 per cent) from Poland; seven (3.5 per cent) from Denmark; fifteen ( 7.5 per cent) from Rus'; nineteen ( 9.5 per cent) from Lithuania; twenty-four (12 per cent) from Livonia; thirty-one (15.5 per cent) from Prussia ${ }^{14}$ and thirty-five (17.5 per cent) students from Sweden. It was impossible to determine the origin of three persons (1.5 per cent). It is noteworthy that throughout that period as many as fifty-one students ( 25.6 per cent) were from the countries, for which no places at the Seminary were earmarked. ${ }^{15}$

Between 1626 and 1652 the following countries and regions

${ }^{13}$ Onc person was first indicated as a Wismarian (Mecklenburg) and again as a Saxonian. The other three were referred to as germanus. Those students must have been from Germany, because in the list of 1585-1602 a local German was registered differently, as lithuanus ex germanis.

${ }^{14} \mathrm{At} \mathrm{least}$ two of that number were from Eastern or Ducal Prussia.

${ }^{15}$ Some areas (Finland, Lapland and Samogitia) here are attributed to those earmarked for the Scminary, although nominally, kecping to the letter of the regulations, they should be treated as having no places. The percentage of the students from those countrics was 1.5 . 
were represented among the total number of 170 students: Bavaria, Bohemia, Denmark, Estonia, Hungary, Moravia, Norway, Pomerania, Sorbia and Sweden - each by one student (0.5 per cent); Podlasia, Silesia and Volhynia - each by three students (1.7 per cent); Couronia and Poland ${ }^{16}$ - each by four students ( 2.3 per cent); Mazovia - by eight (4.7 per cent); the Livonian Palatinate - by nine (5.2 per cent); Rus' - by nineteen (11.1 per cent); Samogitia - by twenty-six (15.2 per cent); Prussia - by thirty-one (18.2 per cent) and Lithuania - by fifty (29.4 per cent) students. It was evident that not all students were from those countries for which the Seminary was founded ${ }^{17}$; however, only 8.8 per cent of admissions (except the Basilians, which were accepted solely through the recommendation of their superiors) on grounds of geographical or national origin exceeded the competence of the Seminary. ${ }^{18}$

Essential changes in the student body in regard to their origin. By the beginning of the seventeenth century it consisted of young men practically from all the regions assigned to the Seminary. The number of foreigners, i.e., others than those from the Grand Duchy of Lithuania or the Polish Kingdom, was ninety-five (47.7 per cent) in the first period, whereas in the second period their number was only twelve (7.0 per cent). The number of local students increased. A relatively small number of foreign students (and converts) in the second period was the result of changes in ideological orientation among local and more distant peoples and states rather than the activity of the Jesuits, who were particularly interested in having more students from the Orthodox Muscovy and Protestant countries. Before and especially during that period Northern and Central Europe was involved in the internal consolidation of both Catholics and Protestants and the deepening of adverse confessional confrontation. Therefore, when Catholic countries established effectively functioning colleges for the converts, Protestant countries perceived the danger of Jesuit activity and isolated themselves from those countries. For example, Sweden and Denmark adopted stringent anti-Catholic laws, and students stopped coming from Scandinavia. ${ }^{19}$ Additionally, after 1618 Europe was rava-

${ }^{16}$ Among those called Poles there were three Basilians, who kncw Russian - they must have been from the castern provinces of the Crown, and one Roman Catholic, probably from ethnic Poland, since he knew only Latin and Polish.

${ }^{17} \mathrm{Herc}$, as well as in the examination of the period between 1585 and 1602, some arcas (Volhynia and Samogitia) were considered, in the spirit of the regulations, as belonging to the catchment region of the Seminary. However, in the course of time, the geographical concepts underwent modifications and accordingly the Estonians and the Couronians should be considered as belonging to the Seminary's arca.

${ }^{18}$ Young men from Mazovia, who made up slightly more than a half of those coming not from the territory of the Seminary, were treated by the Sacred Congregation as belonging to its catchment arca.

"The same is truc of the Pontifical Seminary of Braunsberg. Sec G. Lühr. Die Matrikel ..., 10-11. 
ged by the Thirty Years War, and Lithuania and Poland also fought Sweden several times in the early seventeenth century. It seems that after 1625, when Sweden occupied part of Livonia, no more students from Riga and Estonia were enrolled at the Seminary. ${ }^{20}$ The wars were accompanied by epidemics. Under such conditions both the recruitment of the students and their journeys were very complicated. On the other hand, when the alumni returned back to their Protestant countries, they had no real possibilities for ecclesiastic activities, and their training became pointless. Meanwhile, the position of the Lithuanian Catholic Church consolidated and it needed qualified priests and missionaries in ever increasing numbers. After the formation of the Jesuit province of Lithuania in 1608, the number of students from Poland and Podlasia decreased, while the number of students from Mazovia increased at approximately the same rate (excepting the Basilians). There was also an increase in students from Prussia, and especially noticeable was the growth of the number of students from Lithuania and in particular from Samogitia. Both processes (the decrease of students from abroad and their increase from the Lithuanian Jesuit province) were conditioned by the separate internal consolidation of the Catholic and Protestant churches and their external confrontation in the respective countries and societies.

In the 1585-1602 period Latin naturally was the first language in the Seminary; it was followed by German (ca. eighty students spoke it) and then Swedish (ca. forty speakers); however, just after the establishment of the Seminary the latter was more widespread than German. Quite a number of students spoke Polish. Between 1623 and 1655 about 94 per cent knew it to a greater or lesser degree - therefore (when the use of Latin was not compulsory) it was the main medium of communication for students of various nationalities in everyday life. In the second period about 60-66 per cent of students from Lithuania spoke Lithuanian, and that made up 21 per cent of the total number, i.e., every fifth student was a speaker of Lithuanian. Apart from the Basilians, 78-83 per cent of students from Lithuania spoke Lithuanian. Those who spoke Samogitian made up 16-17 per cent of all the students, and students from Samogitia - 15 per cent. All twenty-six students from Samogitia knew their native tongue. In general, in the 1623-1655 period 35-38 per cent of the students knew Lithuanian and Samogitian. In the 1585-1602 period there were over fifteen Ruthenian-speaking students. In the $1623-1655$ period 84 per cent of students from Russia spoke Ruthenian (21 per cent of all the students). In that respect the situation was similar to that of Lithuanian - every fifth was a speaker of Ruthenian. The majority of the students in the

${ }^{20}$ Only in 1632 two Livonian students, who knew Estonian, were admitted. However, judging from their surnames (Modzielewski and Praznicki) they could hardly have been of Estonian descent. 
second period (75 per cent) usually spoke three languages: Latin and Polish, in addition to their native tongue.

Between 1585 and 1602 the converts, together with neophytes, made up over a half of all the students, thus they predominated at the Seminary. The overwhelming majority of them were former Lutherans. Between 1623 and 1655 the predominating section was the Catholics. From 1626 until 1648 no less than 32 students were Basilian (18.8 per cent) at the PSV. In that period the Ruthenian non-Basilians were Roman Catholics.

In social composition the student body varied from the duke to the peasant. During the whole period the majority were not of noble descent, i.e., they were townsmen and peasants. The former predominated, they came from cities and towns of Bratislava, Braunsberg, Dorpat, Helmet, Königsberg, Kaunas, Lübeck, Riga, Västerås, Vilnius and from many small settlements. However, considering each social grouping separately, the representatives of the gentry numerically occupied the first place, followed by the townsmen and the peasants, the latter being the smallest group. The future career of the alumni did not depend much on their social origin. That was especially true of the Swedish alumni, for example Olaus Lauretii served at the royal court, Magnus Agander became an abbot, Andreas Olaii - a parson of two churches, etc., all of them were of peasant origin. The posts of the alumni from the towns were not worse than those of the gentry, e.g., Jacobus Carmanus from Brandenburg became a canon of Wenden - in Germany that would have been impossible for a person of humble birth. Casparus Schroeterus/Schreter from Livonia obtained a similar post. The Lithuanian Nicolaus Lenčickis (Lancicius) became a famous Jesuit, and the Swede Petrus Montanus was engaged in the service of the sovereign after the minor ordination. The chances of both categories to obtain senior positions seemed to have been more or less the same. The representatives of the gentry, however, more often (by 10 $\%$ ) became clergymen. Therefore the facts that the road to the higher posts was not closed for the alumni of humble descent and that they preferred to take ordinary secular careers lead to the conclusion that the gentry were more disposed to assume social duties.

\section{The Functioning of the Seminary}

The investigation of the development of the Seminary reveals major changes in its activity in the course of the two periods. One of the more important was the change of the manner in which the Seminary was governed and controlled. In both periods all the principal issues were solved in Rome. In the first period, however, local Jesuits were more independent in decision-making, while in the second period Rome was more active in the supervision of the Seminary. Its 
control on the part of the Sacred Congregation, though not very effective, was regular and rigid, therefore the rectors of the Seminary and the Jesuit provincials could not tackle all the academic problems on their own. That was the situation in the second period. In the first period, however, local Jesuits had been more independent in running the Seminary.

After a change of the curators there appeared a tendency to avoid entrants from those countries for which the Seminary was not intended. A feature that was characteristic of both periods was the disposition of the superiors to accept greater numbers of non-Catholic students and their tutelage. Only the Sacred Congregation did not pay any greater attention to that issue.

The tendency of both periods was the reluctance to accept pupils lacking rudimentary education. There were few students who began their studies from the $\mathrm{ABC}$, especially in the second period. In both periods until the years 1644/45 quite a number of students were taught syntax, however, in the second period that number decreased. A far greater number of students were taught subjects at a more advanced level. In 1585-1602 the majority of students studied poetics and rhetoric, and in 1623-1655 - logic. In general, the more advanced the stage of the philosophical discipline (logic, physics and metaphysics) was, the smaller number of students studied it.

Between 1585 and 1602 theology was studied by not less than 38 per cent of students, about 73 per cent of them studying the shorter version of that discipline. From those studying the full four-year programme of theology very few managed to finish their studies. The times were hard for the Catholic Church, and after a year or two of the studies of scholastic theology, Academy students were sent to work for the good of the Church. Between 1623 and 1655 theology was studied by about 51 per cent of the students, and 21 per cent of them studied the shorter course. Of all the learners of the full course, only 41 per cent finished their studies. In the first period there were far more students in the classes of the shorter theology course and respectively more students of the full course in the second period. In the first period slightly more scholars studied theology (due to the shorter course) than to philosophy; the situation was exactly the opposite in the second period, in which the number of those studying theology was larger by 14 per cent compared to the first period.

There were differences in the study of theology and other disciplines depending on the country of the students. In the first period students from the Protestant Western Europe (England, Denmark, Hamburg, Hessen, Lübeck, Saxony Scotia, Westphalia and Germany) rarely chose theology. ${ }^{21}$ Only 12.5 per cent of them studied that sub-

${ }^{21}$ One more circumstance is important in this respect - in German Catholic countries before starting their theological studies the nobility had to be provided with benefices; due 
ject in Vilnius (not one of the seventeen Englishmen, Scotsmen and Danes!); 25 per cent - from the Protestant Livonia; 33.3 per cent from the largely Orthodox Rus'; 36.8 per cent - from the confessionally mixed Lithuania; 37.1 per cent - from Sweden (the policy of Sigismund Vasa promised the Catholics some perspectives); 54.8 per cent from the confessionally heterogeneous Prussia and 83.3 per cent - from the Catholic Poland. With respect to the Poles it must be said that they were few among the total number of students. Nevertheless that number was sufficient to maintain that young men from Poland were favourably disposed towards the studies for priesthood. No doubt, the students from Poland and Prussia studied mostly to become secular priests. Except the Basilians, in the second period theology was studied by 33.3 per cent of students from Rus'; by 35.7 per cent - from Livonia (Couronia and the Livonian Palatinate); 50 per cent - from Lithuania; 61.5 per cent - from Samogitia; 75 per cent - from Mazovia and 80.6 per cent - from Prussia. As the average of those studying philosophy in that period was 57.9 per cent, it could be stated that the students from Samogitia, Mazovia and especially Prussia preferred priesthood. According to the comparative data of the two periods the proportion of theology students from Rus' was the same, correspondingly the number of Livonian students increased approximately by 10 per cent, from Lithuania - by 13 per cent and from Prussia - even by 25 percent.

Since theology was usually studied for more than one year (at least two years for the short course and four years for the full course), the number of theology students must have been the greatest at the Seminary in both periods in comparison to the students of other fields. In general, the beginners predominated in the first period, while the number of the advanced students was greater in the second period. Between 1585 and 1602 few students obtained degrees. If according to the initial assumption of Academia Vilnensis scholastic theology could be studied only by the bachelors and masters of arts, it could be supposed that about 5 per cent were to get at least one of the degrees in the first period and in the second period no less than 30 per cent of the alumni had to graduate with degrees. In the second period no less than every third or fourth student (at least 28 per cent) after a full course of study received degrees in theology, and from those who studied theology for four years 37.5 per cent graduated as doctors of divinity. The students of the Pontifical Seminary were the brightest at least among the non-Jesuits. It could be indirectly surmised that in the second period (1) a greater number of students could be admitted to

to their lack the number of theology students decreased. E.g., in that period at the University of Dillingen theology was studied only by canons or the ones secking canonry. Others graduated as philosophers or lawyers. Scc:Die Matrikel der Universität Dillingen. Dillingen, 1915. Bd. 2. S. 1177. 
the academy for the studies at a higher level and (2) there were more candidates (especially among the local learners), better prepared for the studies. In both periods students from non-Catholic and confessionally mixed countries were treated more favourably than other students.

Although according to the 1585 phrasing of the oath the students were not obliged to become priests, that requirement was introduced on the order of the Jesuit provincial in 1587. The regulations of 1590 did not contain that precondition - thus only between 1587 and 1590 the students pledged themselves to become priests. According to the oath of 1625 the pledge again became obligatory. That essentially modified the character of the Seminary - the institution of Catholic youth education turned into a school of secular priest training. At the Seminary the new oath was introduced only in 1632 . The students did not take their oath in $1639 / 40$ and $1644 / 45$. It seems that the change did not to diminish the number of ordinations, and this is an indication that the students did not avoid being ordained. In the second period there was a marked decrease in the number of those enrolling as monks. In the two periods the orientation of the Seminary was different, depending not only on the change of the curator of the Seminary but also on the policy of the Holy See, and more precisely on the attitude of the popes Gregory XV, Urban VIII and Innocent X towards the pontifical seminaries. Consequently, the Vilnius Semenary was oriented towards the needs of times.

Between 1585 and 1602, 41.3 per cent of the students chose secular priesthood, while 60.3 per cent became clergymen in general, either secular priests or monks; in 1624-1655 the corresponding figures were 69 per cent and 76.1 per cent. Taking into account the Basilians, it could be stated that in the second period as many as 81.3 per cent of the students had been trained as Roman or Greek Catholic clergymen. Due to the change of the oath and the control of the Sacred Congregation, as well as after the permission of the Holy See to admit the Basilians to the Seminary, in the second period the results of its activity in recruiting and training future clergymen improved by about 21 per cent, and in training secular clergymen - by about 27 per cent. The clerical alumni of that period were better qualified for their careers. The majority of the secular priests who graduated in 1585 1602 (36.1 per cent) worked in Prussia and Livonia, while the monks stayed mainly in Lithuania. Altogether twenty-eight alumni worked in Livonia, and twenty-two of them were not of Livonian origin. That was the policy of local Jesuits of enlisting the aid of the alumni of the Vilnius Semenary in the process of Livonia's re-Catholicization. Bearing in mind that the Jesuit Wilhelm Buccius/Bucki issued several valuable Catholic books in Estonian and Latvian and that some alumni of the Seminary taught at the colleges in Riga and Dorpat, it could 
be considered that the contribution of the Vilnius Semenary in strengthening the positions of Catholicism in Latvia and Estonia was quite significant. At least 41 alumni of the second period worked as secular clergymen in Lithuania and Samogitia, and if one counts the bishoprics of Vilnius (Lithuania and Rus') and of Samogitia, that number would be no less than 46; in all the bishoprics of the Grand Duchy no less than 51 alumni (about 66 per cent) were engaged. Seven monks also worked in Lithuania for some time. Thus it could be maintained that about 68 per cent of the clerical alumni of that period stayed in the Grand Duchy, though the Vilnius Semenary most efficiently satisfied the needs of the bishoprics of Vilnius, Samogitia and Warmia, where about 82 per cent of secular priests worked. In that way in the first period the Vilnius Semenary mostly recruited candidates for Jesuits and trained priests for Livonia, and in the second period - for the bishoprics of Vilnius, Samogitia and Warmia; and at the same time it also trained Basilians. In comparison with the neighbouring episcopal seminary the Vilnius Semenary seemed to have prepared rather many priests for Lithuania and Samogitia. In some years of the second period, e.g., in 1637, at the Vilnius Semenary there were more local students (from Lithuania and Samogitia) than at the episcopal seminary, which was specially intended for those lands. ${ }^{22}$ However it would be an exaggeration to state that the activity of the Vilnius Semenary greatly influenced the development of the Catholic Church in the Grand Duchy. The seventeenth century differed from the previous times, and a single seminary, training annually twenty to thirty students, a part of which went to other countries or remained laymen, could not exert any commanding influence. Among its alumni there was only one prominent figure of the Lithuanian Catholic Church - the first bishop of Smolensk and afterwards bishop of Samogitia Petrus Parčevskis (Parczewski). The influence of the other alumni working in the bishoprics of the Grand Duchy was more or less of a local character. Nevertheless, in the Catholic Church of Lithuania (as well as in many other countries), in which the gentry mentality dominated and even moderately trained clergy was scarce, the activity of the Vilnius Semenary was important both for Lithuania and for the neighbouring countries, enabling young men to study at Academia Vilnensis, which was the main centre for the renewal of the Church in the Grand Duchy. In that way the Vilnius Semenary made its contribution in the realization of the decisions of the Council of Trent.

${ }^{22} \mathrm{Cf}$. the lists of students of the Vilnius Scmenary with Ludwik Picchnik. Dzieje Akademii Wileńskiej. Rzym, 1983, vol. 2, 247. Nevertheless, the local Church hierarchs were not always satisfied with the activity of the Vilnius Semenary. Thus, in his report sent to Rome in 1642, the bishop of Samogitia Gcorgius Tiškcvičius (Tyszkiewicz) stated that the seminary of Vilnius would be more useful for him in Couronia, if on the initiative of the Sacred Congregation it would be differently organized and better managed (Relationes status dioecesium in Magno Ducatu Lithuaniae. Romac, 1978, vol. 2, 591. 


\section{The Seminary and the Uniates}

After the union of 1596 the new Uniate Church was rather weak. It had only the old monastery and primary schools. The establishment of a separate seminary was an impossible task at that time, though Sigismundus III had granted the Basilians the right to set up schools on a par with Catholics, and Paul V authorized the Uniate archbishop Rutskyj to establish schools for the youth to study liberal arts and Catholic scholarship, and Urban VIII decreed that in establishing schools Uniate and Catholic bishops had the same rights. The only possibility to train Uniate priests on the academic level was the pontifical seminaries, however, with the exception of the Greek college, in that period the Uniates failed to obtain places, documentarily assigned for their Church. The Holy See wanted the Uniates to be more active in setting up their own seminary. The Roman Catholic alumni of the pontifical seminaries were not allowed to become Basilians. Basilians practically were the only Uniates who used to enrol in pontifical seminaries, and at the PSV they were the only Uniates.

The enrolment of the Basilians at pontifical seminaries could not be massive not only because the number of places was limited, but also due to the differences between the Roman and Greek Catholic doctrines, and especially due to the differences in the medium of instruction and in the subjects of polemical theology. There was a danger of the Latinization of the Uniate rite, which might lead to the disappearance of the Church itself. Possibly that was the reason that in the second quarter of the seventeenth century the Basilian students stayed at the Seminary for a year or two and very few completed the full course of their studies. On the other hand their primary schools were few and weak and did not turn out enough candidates, capable for academic studies. In the course of time the number of Basilian students decreased.

The Basilian alumni of the Vilnius Semenary contributed to the realization of the church union. Due to the absence of the student lists of the period between 1603 and 1625, it is impossible to determine how many and which Basilians studied at the Seminary in the initial period of the reorganization of the Order and materialization of the union. The data related to later years showed that there were Basilian students at the Seminary until 1648 . Several alumni became well known personalities: the Uniate bishops Paulus Ovluczynski, Athanasius Fors/ Furz and Benedictus Glinski, archimandrites Joseph Grodzicki and Michael Paszkowski (the latter became the titular bishop of Smolensk) and procurator general of the Uniate Church in Rome Gregorius Bienkowski. 


\section{The Pontifical Seminary of Vilnius and Other Seminaries}

Extremely close ties were maintained between the Vilnius Semenary and the Braunsberg Seminary, functioning at the colleges belonging to the same Jesuit province. The learners from Vilnius had to be sent to Braunsberg for lower level-studies and those from Braunsberg - to Vilnius for advanced studies, in practice however, that rule was not always observed. It was more strictly adhered to at the start, while later not only poetics and rhetoric, but also syntax and grammar were regularly studied, and in certain cases students could begin their studies even from the $\mathrm{ABC}$ in Vilnius. On the other hand, when the Jesuit College in Braunsberg was permitted to introduce a course of philosophy and a short course of theology, the number of students going for the studies in Vilnius began to decrease after 1592. The opposite movement began: the students of Vilnius, studying philosophy and even the short course of theology, started coming to Braunsberg. ${ }^{23}$ After 1641, when the full course of theology was introduced there, only four Braunsberg students came to Vilnius: in 1643 - Matthias Poduski Kiesz to study theology for the third and fourth years of his studies, the Basilians Thadeus Zakrzewski and J. Grodzicki and in 1649 Michael Zienicki to study moral theology with the nuncio's permission. At the same time some students of Samogitian or even Lithuanian origin, having studied philosophy and theology at the PSB, had never been students of the Vilnius Semenary, among them Lithuanian students, who studied at Braunsberg in 1647-1651, Georgius Giedraitis (Gedroyć), Joseph Piersienski/Pirczewsky, the Basilian Martianus Bialosor, Wladislaus Orda/Horda. ${ }^{24}$ Nevertheless many students studied at both seminaries - during the period under investigation their total number must have been no less than 153: about 71 (35.6 per cent) in 1585-1602 and 30 (17.6 per cent) in 1623-1665. Studies on exchange basis were also practised, e.g., in 1612 Laurentius Schen went to Vilnius and Andreas Chorius to Braunsberg; similarly Joannes Eidman and Joannes Olpusz from the PSV studied at Braunsberg in 1619..5

In the initial stage of the Vilnius Semenary the students of the Olmouc Seminary often travelled to Vilnius, too - at least twelve cases are documentarily attested. ${ }^{26}$ However, fewer students went from Vilnius to study in Olomouc - between 1585 and 1602 there were at least

${ }^{23} \mathrm{Cf}$. The trip of Jacobus Eicholc/Echolz in 1596; Catalogus alumnorum pontif. Vilnae ... F. 17; G. Lühr. Die Matrikel ... 49, N. 263; and of Joanncs Human and Joanncs Eidmann in 1616 and 1619 ; ibid. 72, N. 479, 73, N. 486.

${ }^{24}$ Scritture ..., V. 365. F. 351-353; G. Lühr. Die Matrikel ...,93, N. 713, 715; 94, N. 721, 727. The information concerning Bialozor and Orda is insufficient, i.c., it is not clear if they studied for a year at the PSV before going to Braunsberg.

${ }^{25} \mathrm{G}$. Lühr. Die Matrikel ..., 66, N. 422, 429; 72, N. 479, 480).

${ }^{26}$ Olaus Alginus; scc A. Theiner. La Suede et le Saint-Siege. Paris, 1842, vol. 3, 369; Catalogus alumnorum S. .... F. 17. N. 9; Catalogus alumnorum pontif. Vilnae ... F. 18;

Petrus Andrcac; scc G. Lühr. Die Matrikel ... S. 31, N. 33; Acta Sacrae Congregationis 
four Vilnius students ${ }^{27}$ at the Olmouc Seminary, and no students were found in the second period. Study trips to and from Olomouc were common, because according to A. Possevino's project young ex-Protestant men had to be sent further so as to avoid the danger of apostatizing from Catholic faith in their studies. That directive was recorded in the regulations of the Olmouc and Braunsberg Seminary and probably in those of the Vilnius Semenary. ${ }^{28}$ Therefore at the beginning they studied at Olomouc, then returned to Vilnius, while others through Olomouc went to Rome or some other university cities. Although the Olmouc was also intended for the young men from Rus' or Lithuania (Rusia seu Lituania), in the period between 1579 and 1624, i.e., before its patronage was taken over by the Sacred Congregation, its Ruthenian students were mainly from the Russian lands, belonging to Po-

de Propaganda Fide res... P. 132, N. 202; Z. Hojda. Collegia ... S. 79, N. 41; Catalogus alumnorum Pontificis Maximi ...);

Laurentius Boicrus/Bojer; sec A. Theiner. La Suede ..., vol. 3, 368; Acta Sacrae Congregationis de Propaganda Fide res ... . p. 125. N. 37; Z. Hojda. Collegia ... S. 80. N. 50; Catalogus alumnorum pontif. Vilnae... F. 10;

Isaac Fechtinus/Factiri/Fcuctinus/Fenctino/Fentinus, etc.; sec $A$ cta Sacrae Congregationis de Propaganda Fide res.... p. 124, N. 36; A. Theincr. La Suede ...vol. 3, 369; Catalogus alumnorum pontif. Vilnae ... F. 7;

Henricus Gralcwski/Kralenski; sec Acta Sacrae Congregationis de Propaganda Fide res..., p. 133, N. 254; Catalogus alumnorum Pontificis Maximi ...; Catalogus alumnorum pontif. Vilnae... F. 8;

Otto Groshaus; sec V. Helk. Die Jesuiten in Dorpat 1583-1625. Odense, 1977, 242, 319; Catalogus alumnorum pontif. Vilnae ... F. 10;

Pctrus Cuprimontanus/Caprimontanus; scc A. Theincr. La Suede..., vol. 3, 368, 372; Acta Sacrae Congregationis de Propaganda Fide res... , p. 124, N. 23; Z. Hojda. Collegia... p. 82, N. 59; G. Lühr. Die Matrikel ... p. 38-39, N. 123; Catalogus eorum ...

Fridericus and Mathias Markmanus; sce Catalogus alumnorum Pontificis Mcximi ...; Catalogus alumnorum pontif. Vilnae... F. 14, 23; Acta Sacrae Congregationis de Propaganda Fide res..., p. 133, N. 249, p. 137, N. 361;

Marcus Merclcrus; scc Acta Sacrae Congregationis de Propaganda Fide res..., 125, N. 40; Catalogus alumnorum pontif. Vilnae... F. 14;

Andrcas Tallcrus/Stallcrus; scc Acta Sacrae Congregationis de Propaganda Fide res..., 126, N. 67; Catalogus alumnorum pontif. Vilnae... F. 5;

Albertus Svanto/Suanto; sec Acta Sacrae Congregationis de Propaganda Fide res... P. 122, N. 6; A. Theincr. La Suede...vol. 3, 368; Catalogus alumnorum pontif. Vilnae... F. 22.

${ }^{27}$ Laurentius Borlangius/Borclangius; sec Catalogus alumnorum pontif. Vilnae... F. 17; Acta Sacrae Congregationis de Propaganda Fide res..., 135, N. 294; Z. Hojda. Collegia.., 81, N. 51 ;

Joanncs Malachius; scc Catalogus alumnorum pontif. Vilnae...F. 24; V. Helk. Dansknorske studierejser.. 309; Z. Hojda. Collegia...76, N.18;

Joanncs Montanus / dc Montc; scc Catalogus eonum...; Acta Sacrae Congregationis de Propaganda Fide res..., 126, N. 65;

Antonius Alcxandri Posscvinus/Possovinus; scc Catalogus alumnorum pontif. Vilnae... F. 6; Acta Sacrae Congregationis de Propaganda Fide res... , 131, N. 178;

A. Staler (Z. Hojda. Collegia ..., 87, N. 100).

${ }^{28} \mathrm{~A}$. Theincr. La Suede ..., vol. 2, 418: Qui cx plaga magis scptentrionali evocabuntur, uti cx Suctia, Gothia, Finlandia, corumque alicui videretur impendere periculum ob patriac propinquitatem, vel redeundi ad vomitum, vel ut propinqui ex affines cum cvocarent: is Olcmucium tanquam ab interiorem et tutiorem continentis partem, transmitti potcrit. 
land. A conclusion like this is supported not only by some recorded data, but also by the fact that in that period at the seminary, in contrast to the Vilnius Semenary, there were rather many Poles, and from the total number of 602 , whose geographical or national origin was indicated, only one student was from Lithuania, ${ }^{29}$ and there were no Lithuanian students at all in 1631, 1632 and $1633 .{ }^{30}$ It can be maintained that that was due to the relative proximity of the Olmouc Seminary to the south-eastern lands of the Polish Kingdom. Later the local Jesuits, as well as those of Graz and Prague seemed to have avoided accepting students, sent by Church superiors of other countries. ${ }^{31}$

Students from other Central and Western European pontifical seminaries or colleges did not go to Vilnius. Only one case is known: L. Boierus/Bojer, before coming to Vilnius in 1578, had been a student of the pontifical seminary of Prague. ${ }^{32}$ The students of the PSV also rarely studied at the seminaries or colleges of Prague, Graz, Vienna or Rome. ${ }^{33}$ Only the following cases are known: Georgius Just ${ }^{34}$ was sent to Prague before 1590, Samuel Graben ${ }^{35}$ - before 1592; Henricus Schachtius ${ }^{36}$ did his studies there in 1607-1608. Jacobus Kydius went from the Olmouc Seminary to study in Graz, where he obtained the degree of the bachelor of liberal arts and philosophy in 1616 and then, in 1622, he went to Vienna for a half-year's study. ${ }^{37}$ From 1 September 1630 until 8 November 1631 the Lithuanian Basilian Philipus Borowik/Borovius and Jasaphat Isakowicz studied at the of Prague Pontifical Seminary. ${ }^{38}$ The students of the Vienna Pontifical Seminary were Zacharias Iłkowski (from 8 December 1637 until Octo-

${ }^{29}$ Joanncs Momonowitz; scc Acta Sacrae Congregationis de Propaganda Fide res ... . N. $124 \mathrm{c}, 131$.

${ }^{30}$ Visite ... V. 10, F. 161; V. 11, F. 63; V. 12, F. 16.

${ }^{31}$ Maybe that was the reason why in 1646 the bishop of Smolensk, seeking to take over the places, intended for Muscovites, preferred to get them at Braunsberg and Vilnius rather than at Olomouc; sce Supplicationes Ecclesiae unitae Ucrainae et Belarussiae. Romac, 1960), vol. 1, 152. Concerning the PSO and the Pontifical Seminary of Prague sce A. Grickevičius. Popiežiškoji ..., 143-144. Concerning the scminary of Graz sec further in this paper.

${ }^{32}$ Z. Hojda. Collegia ..., p. 80, N. 50; L. Picchnik. Dzieje ..., 81.

${ }^{33}$ The situation in Rome can be conccived on the basis of the lists of Collcgium Germanicum and Collegium Urhanum, as well as of various documents of the Sacred Congregation. The latter do not contain any Lithuanian requests. As an exception is the application of the Samogitian bishop G. Tiškevičius (Tyszkiewicz) concerning the admission of Joannes Szemet, an alumnus of the PSV; however, the CS declined the request, recommending the applicant to continuc his studies cither in Vilnius or in Braunsberg; sec Acta Sacrae Congregationis de Propaganda Fide. V. 13. F. 438; Lettere volgari ... V. 19. F. 139.

${ }^{34}$ Catalogus eorum...

${ }^{3 .} \mathrm{Cf}$. Acta Sacrae Congregationis de Propaganda Fide res ..., p. 147. N. 46; G. Lühr. Die Matrikel ..., 35-36. N. 85; Status ... . F. 292r.

${ }^{36} \mathrm{Z}$. Hojda. Collegia ..., 89.

${ }^{37}$ Acta Sacrae Congregationis de Propaganda Fide res ... P. 142. N. 516; V. Helk. Dansknorske studierejser ..., 286.

${ }^{38}$ Visite ... V. 8. F. 333-334; V. 11. F. 62. 
ber 1639) and after his departure - M. Paszkowski. ${ }^{39}$ The Swede A. Tallerus/Stallerus came a doctor of theology ${ }^{40}$ and studied at the German College of Rome between 1587 and 1591, the Dane Mathias Gerhardi/Maricampus/Marfeld ${ }^{41}$ also studied law there 1606-1607. After 1590 Thomas Hattonus/Attonus ${ }^{42}$ was sent to the English College, and after 1593 - Samuel Loffgnor/Leukenor/Levknor. ${ }^{43}$ Fridericus Duker/ Dieker, ${ }^{44}$ who later became a Jesuit, studied at the Jesuit College of Rome in 1604-1607, and so did the above-mentioned H. Schachtius ${ }^{45}$ in 1610. Only several scholars seem to have studied and/or taken their degrees there: Mathias Montanus ${ }^{46}$ - in 1587-1591(?), Joannes Billius $^{47}$ - after 1590, and S. Graben became a doctor of medicine about $1592 .{ }^{48}$ In 1592 or at some later time, the Ruthenian Laurentius Kaminsky also went to Rome, ${ }^{49}$ however, no information about his studies there was found. The aforementioned Basilians studied at the Greek College: P. Borowik/Borovius - in 1633-1638 and Gr. Bienkowski - in 1645-1650.50

${ }^{30}$ D. Blażejovskij. Byzantine ..., 160

${ }^{40}$ G. Lühr. Die Matrikel ..., 33-34. N. 60; Catalogus alumnorum pontif. Vilnae ... F. 5; Z. Hojda. Collegia ... p. 87. N. 100); Catalogus eorum ...; Status ... F. 292r; P. Schmidt. Das Collegium ..., 303; Acta Sacrae Congregationis de Propaganda Fide res ..., 126. N. 67.

${ }^{4}$ P. Schmidt. Das Collegium ..., 275; V. Hclk. Dansk-norske studierejser ..., 311.

${ }^{42}$ Cf. Catalogus alumnorum Pontificis Maximi ...; Alumni S. D. N.... F. 294r; Status ... F. 292r; Catalogus alumnorum pontif. Vilnae ... F. 11.

${ }^{43}$ Catalogus alumnorum pontif. Vilnae ... F. 19; Threnodie in obitum $\langle\ldots\rangle$ Alberti Radziwil/li], $<\ldots>$ supremi M.D.L. marschalci, Caunen/sis/ et Romburgen/sis] $<\ldots>$ capitanei. A. praecipua iuventute Parthenicae sodalitatis in Acad. Vilnen. S. I. Conscripte <...>. Vilnac, 1593.

${ }^{44}$ V. Helk. Die Jesuiten ... 321, 249

${ }^{45}$ A. Picpcr. Die Propaganda-Kongregation und die nördlichen Missionen im 17. Jahrhundert. Köln, 1886, 13.

${ }^{46}$ Vilna missus Romam ad theologiam <..> > G. Lühr. Die Matrikel..., 40, N. 146. Romac theololgiam| audit. Catulogus alumnorum pontif. Vilnae... F. 18. Concerning the date cf. J. Poplatck. Wykaz ..., 229. N. 46; Catalogus alumnorum pontif. Vilnae ... . F. 18. In Rome non-Jesuit Scandinavians were admitted to the German College, thus it is quite believable that M. Montanus was a student namely of that college. However, he is not to be found in the lists of the students or convectors of the German College; see P. Schmidt. Das Collegium ..., 217-321. Therefore it is possible that he studied at some other college (English?) or was enrolled by some other name. The same is truc of J. Billius.

${ }^{47}<\ldots>$ Romam ivit et theologus saccrdos discessit in patriam $<\ldots>$; sec Catalogus alumnorum pontif. Vilnae ... F. 5; concerning the date cf. Catalogus et examinatio ... F. 36v; Catalogus alumnorum Pontificis Maximi ...; Status ... F. 292r; Catulogus alumnorum pontif. Vilnae ... F. 5; That person was not indicated in the list of the students of the German College; sce P. Schmidt. Das Collegium ..., 217-321. In the list of the PSV in 1592, however, he was introduced together with A. Staler: D. Joannes Bilius Suec[us] Sacerdos[,] D. Andrcas Stalcr|us| Succ|us| Saccrdos. Romac degunt, suis futuri p[er]utiles; cf. Status ... F. 292r. Concerning the studies of the latter at the German College there can be no doubts.

${ }^{4}<\ldots>$ missus Romam, ubi factus medicinac doctor $<\ldots>$. Sec Acta Sacrae Congregationis de Propaganda Fide res ..., 147. N. 46; also G. Lühr. Die Matrikel ..., 35-36, N. 85.

${ }^{40}$ Romam missus, sec Catalogus alumnorum pontif. Vilnae ... F. 19. D. Blażejowskij. Byzantine ..., 61 .

${ }^{51}$ Monumenta ..., T. 3, N. 1. P. 1. Nota 3; D. Blażcjowskij. Byzantine ..., 83. 
Thus between 1585 and 1602 quite a number of students (especially the Scandinavians by the start of the seventeenth century) seem to have studied at two to three (Braunsberg, Vilnius, Olomouc), sometimes even at four to five seminaries (Braunsberg, Vilnius, Prague, Olomouc, the German College) before graduation, while between 1623 and 1655 only the Basilians (except the Braunsberg Seminary students) used to go abroad and study at the pontifical seminaries and colleges. They were sent not by the local Jesuit superiors but by the Uniate metropolitan. At other pontifical seminaries actually there were very few students of Lithuanian origin (except the ones indicated above). ${ }^{51}$

Some of the students, before graduating from the Seminary, had studied at Protestant universities. E.g., the Norwegian Erland Haldorsen $^{52}$ had studied in Rostock and Wittenberg in 1594 and 1595, the Cimbrian Nicolaus Sartorius alias Sylvius ${ }^{53}$ - in Copenhagen in 16121613, in Rostock since February 1614 and in Wittenberg - since September of the same year.

Several Vilnius Semenary students continued their studies at the universities of some Catholic countries and later embarked on lay careers. In 1592 Joannes Montanus / de Monte (Livonia), presumably a former student of the Olmouc Seminary, was enrolled at the University of Dillingen. ${ }^{54}$ In 1597 the Lithuanian ex-monk (a Jesuit?) Jonas Kimbaras was admitted to the University of Graz and on 13 April 1598 was awarded a bachelor's degree of liberal arts and philosophy and in 1600 he probably presented M.A. thesis. ${ }^{55}$ Jacobus Bondaeus/Bundaeus (Gotland) studied in Würzburg since April 1604 and in Bourges since January 1606; there he became a doctor of both civil and canon laws early in 1607 and some time later he studied in Orleans. ${ }^{56}$ Quirinus Cnoglerus (Austria) studied at the University of Padua in 1606. ${ }^{57}$ The ex-Jesuit Petrus Graben became a doctor of civil and canon laws at some university after $1606 .{ }^{58}$ After his studies in Rome about 1617 1618 the Jesuit H. Schachtius (Schleswig) also studied theology in

${ }^{51}$ E.g., among the students of the German College there were only several people: Basil Farmola - in 1578-158() and Ludovicus Hosius - in 1579; both were from Vilnius; sce P. Schmidt. Das Collegium ..., 241, 259.

:2. Hclk. Dansk-norske studierejser ..., 232.

5.Ibid., 395.

${ }^{54}$ Cf. Acta Sacrae Congregationis de Propaganda Fide res .., p. 126, N.65; Die Matrikel der Universität Dillingen. 19(1)9. Bd. 1, p. 205, N. 180).

${ }_{55}^{55}$. Andritsch. Die Matrikel der Universität Graz. Graz, 1977, p. 18. N. 41; p. 102; R. Plečkaitis. Feodalizmo laikoturpio filodofija Lietuvoje. Vilnius, 1975, 101, 510. Conccrning this scholar sec also Alummi S. D. N. ... F. 294r; R. Plcčkaitis. Feodalizmo ..., 102.

${ }^{56} \mathrm{~V}$. Hclk. Dansk-norske studierejser ..., 175.

${ }^{57}$ R. Plcčkaitis. Feodalizmo ..., 436.

${ }^{58}$ Cf. G. Lühr. Die Matrikel ..., p. 49, N. 265; V. Hclk. Die.Jesuiten ..., 227. The fact that P. Graben took that degrec at a Catholic rather than at a Protestant university is indirectly attested by the fact that he subsequently served as Sigismund Vasa's secretary. 
Würzburg and Bamberg, ${ }^{59}$ and J. Kydius (Denmark) did his studies in Perugia in 1623-1630. ${ }^{60}$ In 1647 Andreas Borzecki/Borzęcki (Bohemia) went to the University of Krakow, but did not stay there for long. ${ }^{61}$

After their studies in Vilnius or at any other Catholic university some students went to a Protestant school. The above-mentioned Otto Groshus/Groshaus (Couronia) was enrolled in Köln in October 1593 and in May of the following year he was conferred a degree of the bachelor of liberal arts and philosophy, and a year later in March a master's degree. Between 1598 and 1600 he seems to have studied in Rostock. ${ }^{6}$ Guilelmus Ravn-Corvinus (Denmark) was enrolled at the University of Königsberg in November 1599; in 1603-1604 he studied medicine in Basel and on 8 October 1605 became a doctor of medicine. ${ }^{6.3}$ Thomas Essenius / ab Essen (Couronia) was admitted to the studies in Rostock in 1600. ${ }^{\text {(4 }}$ Andreas Radau (Prussia) became a Jesuit, but later left the Order and supposedly entered the University of Königsberg in 1601. ${ }^{65} \mathrm{~J}$. Bondaeus/Bundaeus (Gotland) was in Helmstedt in 1609, in the spring of 1615 - in Rostock and in the autumn - in Wittenberg. ${ }^{66} \mathrm{M}$. Merfeldt (Denmark) studied medicine in Leiden since 28 June 1611. ${ }^{67}$ Joannes Mortensen/Utbynaeus (Denmark) studied in Giessen in 1617, in Heidelberg - in 1620, in Tübingen - in 1620-1622; in 1622 he also studied medicine in Strasbourg and since the beginning of 1627 - in Bautzen. ${ }^{68}$ Some alumni went to Protestant universities in order to convert their countrymen to Catholicism and to invite them to study at the pontifical seminaries and universities of the Catholic faith. ${ }^{69}$

${ }^{59}$ A. Pieper. Die Propaganda-Kongregation ..., 13.

${ }^{(10} \mathrm{V}$. Helk. Dansk-norske studierejser ..., 286.

${ }^{61}$ Laureae ... F. 186.

${ }^{(2}$ V. Helk. Die Jesuiten ..., 319. Nota 24.

${ }_{63}^{6}$ V. Helk. Dansk-norske studierejser ..., 356.

${ }^{64} \mathrm{~V}$. Hclk. Die Jesuiten ..., 318. Nota 16.

${ }^{65} \mathrm{~V}$. Helk. Ibid., 225.

${ }^{66}$ V. Helk. Dansk-norske studierejser ..., 175.

${ }^{67} \mathrm{~V}$. Helk. Ibid., 311.

${ }^{68} \mathrm{~V}$. Helk. Ibid., 364. This source also contains an indication that the same person as a student was in Braunsberg on 3 August 1648 - duc to a grcat difference in time that seems highly improbable. It is possible that at some of the indicated universities his namesake might have becn registered, too, because the Vilnius Semenary student, 23 years old, studied philosophy; sec Catalogus omnium ...., thus 25 years would have separated the studies in Vilnius from those in Bautzen, indicated by V. Helk, and the student must have been 48 .

(1)The convert students of the seminary were encouraged to recruit candidates among their Protestant countrymen. There are records showing that with that aim in view they used to go to Protestant universities. The directive of sending scminary students to their native countries to recruit new entrants was recorded in the regulations: si quid autem de tota pensionum summa aliquando superesset, id $\mathrm{vcl}<\ldots\rangle \mathrm{vel} \mathrm{remittendis} \mathrm{etiam} \mathrm{domum,}$ ut alios adducant $<\ldots\rangle$ id impendi poterit; sec A. Theincr. La Suede ..., vol. 2, 417. In the opinion of J. Poplatck, in the "statutc" of the Vilnius Semenary there was a special article; sec J. Poplatek. Zarys ..., 6. The sources also contain indications that a number of the PSV 
There were several reasons why few students went to study abroad and nearly all the local ones preferred to stay at their school. The most important cause was the full course of theology, conducted at Vilnius, the degrees, conferred here, and in general - the Academy was well known and had the reputation of being a good school. With the exception of medicine and law, students were more often sent or went on their own for the studies at the Academy than from there to any other schools. The distances were also an important factor. Ultimately, the confessional situation in Lithuania was more favourable for the Catholic Church than in Germany, England or the Scandinavian countries. Therefore more places in Rome and other Western and Central European universities were allotted for the students coming from the entirely or partly Protestant countries.

Nearly all those Vilnius Pontifical Semenary alumni, who went to study at other universities and did not become the students of the Seminary were mainly from the lands other than those of the Grand Duchy - they were mostly from Protestant countries. Those who went abroad and did not enrol at pontifical seminaries and colleges did not intend to become clergymen - they evidently hoped for profitable lay careers. The alumni of Catholic origin and those who looked for careers in Catholic countries, chose Italian. French, Austrian or Southern German universities. Those for whom the Catholic reputation was not prospective in their countries studied at Protestant universities.

The place of the Seminary can also be determined by comparing it with other similar contemporary institutions in respect to size. The Pontifical Seminary of Vienna was annually assigned 1,360 gold scudi for the maintenance of forty students. The Pontifical Seminary of Prague had 1,532 scudi for thirty students each year. The Braunsberg Seminary received 1,200 scudi for twenty-five students and the Olmouc Seminary - 2,400 scudi for a hundred students. The Pontifical Seminary of Fulda had 1,200 scudi for forty students. ${ }^{70}$ Thus the Vilnius Seminary must have been the smallest pontifical seminary at least in Central and Eastern Europe (1,200 scudi - twenty students). ${ }^{71}$ Ho-

students went to Protestant universitics, spent a year or a half there and then returned back to some pontifical seminary, while some students returned there after a longer term of study. E.g., in that way J. Malachius seems to have brought two countrymen to the Olmouc Seminary from Wittenberg: Discessit in Daniam 1599 27. maii, inde Olomucium cum duobus nobilibus Danis, quos informaverat Wittebergac; G. Lühr. Die Matrikel ..., 53. N. 297. Further information of that kind can be found in V. Helk's publication Dansknorske studierejser....

${ }^{71}$ Visite ... . V. 4. F. 72-73. That source did not contain any indication of the student numbers at the Scminary of Vienna, but it was presented in the jubilee edition of the SC; sec Sacrae ..., 495. The number of students in Fulda was also not quite clear - according to other sources it must have been sixty.; sec B. Duhr. Geschichte der.lesuiten in den Ländern deutscher Zunge. Freiburg im Breisgau, 1907, vol. 1, 305.

${ }^{71}$ It is casily noticcable that the Braunsberg Scminary had to support a much greater number of people with the same resources. That difference could be accounted for by the 
wever the episcopal seminaries of the Grand Duchy and the Polish Kingdom do not stand comparison with the Vilnius Semenary, which was much bigger, and only the biggest - the seminaries of Braunsberg and Pultusk - equalled it in size..$^{72}$ In comparison with the pontifical seminaries of the Habsburg lands the Vilnius Semenary was easier to control and thus it functioned in accordance with the confessional policy of the Holy See, in actual fact its activity satisfying the Vatican. Its functioning was only insignificantly corrected, while some other seminaries (those of Vienna, Prague, Loreto, Fulda and Dillingen) were reformed in 1627-1628 and 1637.

One of the main obstacles for the successful functioning of the pontifical seminaries was great distances and primitive communications. Quite a serious obstacle was the discrepancy between the objectives of the founders and the interests of the administrators of the seminaries. E.g., the Jesuits were accused of using seminaries for the recruitment of members for their noviciates. The Vilnius seminary could be an example of such a situation: it always lacked students from those countries for which it was established and nearly always had them from those lands which were outside its catchment area.

One more obstacle was the clash of universal and local interests. In the eyes of the Reformation ideologists, the religions reform was 'the genie out of the bottle', while the actions, designed by the hierarchs of the Catholic Church, often failed due to the local intricacies and complexities, and still worse, as a result of the nonchalant defiance on the part of local lay and Church officials. For example the pontifical seminaries of Olomouc, Prague and Graz refused to admit the Ruthenians, ${ }^{73}$ though the Uniate Church was in great need of qualified clergymen. Another example could be the changes in the status of the Seminary of Graz. ${ }^{74}$

following facts: (1) initially a part of that sum had to cover the needs of the Translators' Scminary, and (2) the cost of living in Vilnius was much higher than in Braunsberg - a provincial town.

${ }^{72}$ Dzieje teologii katolickiej w Polsce. Lublin, 1975, vol. 2, part 2, 86.

${ }^{73}$ A. Grickevičius. Popieži.̌̌koji ..., 143-144.

${ }^{74}$ The Pontifical Scminary of Graz was set up by Gregory XIII. Sixtus V to some extent changed the Church policy of his predecessor, as a result the Jesuits fell into disfavour and the pontifical seminarics lost support.; see Franz Kroncs. Geschichte der Karl Franzens-Universität in Graz. Graz, 1886, 240. Instead of the moncy from Rome, the scminary of Graz was granted some local Church land. His successor Clement VIII endorsed the previous decision: Graccense |scminarium -A.G.] sub regimine corumdem Patrum [jesuitarum - A.G.]; hoc habebat provisionem a Sedc Apostolica fl. 1300, quorum loco a Sixto V. fuit unitum monastcrium Chartusianorum Troni S[anctissi]mac Trinitatis in Patricah $<\ldots>$ pro alumnis $12 \mathrm{et}$ unio a Clemente VIII. fuit confirmata $<\ldots>$. Acta SC de Propaganda Fide Germaniam spectantia. Paderborn, 1962, 485. Nevertheless Rome considered this seminary pontifical, and for some time in that respect there were no differences of opinion between Rome and Vienna. Later, however, possibly after the establishment of the Sacred Congregation (1599) and the introduction of its control over the pontifical seminaries $(1600)$, the attitude of the dukcs changed. They began treating it not as a pontifical but as 
In general, the Sacred Congregation favourably treated the existence of the pontifical seminaries and the activity of their alumni. That kind of attitude was made manifest by contemporary and later events, as when im organizing its first mission to Sweden, the Sacred Congregation appointed the Jesuit $\mathrm{H}$. Schachtius ${ }^{75}$ - a former student of the pontifical seminaries of Braunsberg, Vilnius and Prague - as its head. At the turn of the eighteenth century the Sacred Congregation debated the necessity of the seminaries, the expedience of the high costs of their maintenance and drew a conclusion that the pontifical seminaries were indispensable. ${ }^{76}$

a regional institution under their patronage; cf. Acta $S C$.., 624, 625, 643; F. Kroncs. Geschichte ..., 285. The Sacred Congregation made unsuccessful attempts to change the situation and place the seminary of Graz again under its aegis; cf. Acta SC ..., 652. Finally, in 1647, the Holy See lost control over that seminary and could not influence its activity any more; scc ibid. 664.

${ }^{75}$ A. Picper. Die Propaganda-Kongregation ..., 13.

${ }^{76}$ Sacrae ..., 503-504, 505. 